\title{
EDITORIAL
}

\section{COISA DE MULHER}

Quando pensamos em publicar um dossiê com o título "Coisa de Mulher", queríamos fazer uma provocação: ironizar o tão afamado clichê de que algo, reconhecidamente não pertencente ao universo masculino, figurando-se de importância menor e reduzido ao universo feminino.

Não só o quotidiano, mas a produção filosófica, artística e científica conta com insignes representantes mulheres, porém, secundarizadas e até mesmo silenciadas, razão óbvia de a produção oriunda desses e de outros campos aparecer como, majoritariamente, dos homens.

Visando contribuir para a correção desse fato, a Revista Jangada, com o título "Coisa de mulher", esperava receber artigos dedicados à análise de trabalhos realizados por mulheres no campo das artes (Literatura, Música, Cinema, Pintura, Arquitetura, Dança, Escultura etc.) e da Teoria, Crítica e História da Arte, atentando para o fato de que, quando abrimos os manuais de história da arte, por exemplo, dificilmente nos deparamos com obras das mulheres escultoras, pintoras, fotógrafas etc. Com frequência, também não somos instruídos sobre as obras das mulheres cineastas, arquitetas, musicistas etc. Na literatura, temos muito mais à nossa disposição as obras dos escritores do que as das escritoras. Esse desfalque é consequência de um longo processo histórico que alheou as mulheres dos espaços públicos e dos direitos civis, com drásticas consequências para a vida social. Não implica, porém, dizer que as mulheres aceitaram os limites que lhe foram impostos.

Lembrando o poema "Com licença poética", de Adélia Prado, "desdobramos" a expressão "coisa de mulher", carregada de preconceito quando destinada a restringir o alcance das ações das mulheres, propondo que as coisas não são prioritariamente de homens ou de mulheres. As mulheres têm cada vez mais ocupado espaços que antes lhes eram negados, seja nas artes, na ciência, na política, na economia etc. É inegável, no entanto, que muitas contribuições das mulheres para as Ciências Humanas, Letras e Artes, por exemplo, aguardam por trabalhos de pesquisadores interessados em ampliar a historiografia, e era com esse intuito que esperávamos contribuições para o presente dossiê. 
Propomos que trabalhos sobre obras de mulheres que conquistaram reconhecimento ao logo dos anos mereceriam todo nosso respeito e também seriam acolhidos no presente dossiê. Enfatizamos, porém, que havia muito por fazer a fim de romper o silêncio imposto às obras de mulheres que seguem excluídas dos estudos das artes e da cultura de modo geral.

Chegado o momento de publicarmos o dossiê, perguntamo-nos se havíamos alcançado o objetivo pretendido. A resposta é sim, a quantidade de trabalhos avaliados e aprovados levounos à decisão de publicar dois volumes para o presente dossiê.

Esse primeiro volume inicia com um artigo dedicado à obra da escritora brasileira contemporânea Conceição Evaristo. Ângela Froés, autora do artigo "A ficcionalização da memória e o trauma na composição do romance Ponciá Vicêncio (2003), de Conceição Evaristo", analisa experiências traumáticas das personagens do romance, relacionando-as a aspectos importantes da história dos afrodescendentes. Ao final do volume, reproduzimos uma entrevista com Conceição Evaristo, realizada em 2007 por Aline Arruda, como parte de sua pesquisa de mestrado. A leitura conjunta do artigo e da entrevista abre possibilidades de discussões importantes para os estudiosos da obra de Evaristo, haja vista, por exemplo, o que diz a escritora sobre suas personagens. Voltaremos a essa entrevista ao final dessa apresentação.

$\mathrm{Na}$ sequência, temos três artigos dedicados à pintura, fotografia e música, respectivamente. O primeiro, de Luciane de Souza, com o título “A estética do ser-ímã de Hilma Af Klint: um amálgama entre a ciência e a ficção", investiga relações entre a pintura da sueca Hilma af Klint (1862-1944) e teorias científicas que lhe eram contemporâneas. Luís Carlos Branco, com o trabalho intitulado "Reencenação e pós-apocalipse na obra fotográfica de Francesca Woodman”, propõe que Woodman (1958-1981), de modo pertinente, inverte e rasura papéis de gênero em suas fotografias. Isabel de Viana e José Luís de Oliveira, com o artigo “Ópera de mulher: projeto de encenação e interpretação musical”, dedicam-se à análise da interpretação de dez personagens femininas em óperas italianas do século XIX.

Os próximos três artigos são dedicados à obra de escritoras estrangeiras. Daiane Oliveira e Nilson Adauto, com o trabalho intitulado "Sob a pluma da mulher: idealizações e transgressões em Indian (1830), de George Sand", analisam a crítica à sociedade patriarcal realizada pela escritora francesa George Sand (1804-1876) em seu primeiro romance. Luísa Nunes de Oliveira, no artigo "Uma flor em metamorfose", trabalha com os conceitos de violência simbólica, proposto por Pierre Bourdieu, e de ficções lésbicas, proposto por Laura Arnés, para realizar uma análise do conto "Momentos de ser: os alfinetes de Slater", de Virginia Woolf (1882-1941). Valentina Molina, com o artigo "Kümedungun: Trajetórias de vida e a Jangada | nr. 14, jul/dez, 2019 | ISSN 2317-4722 


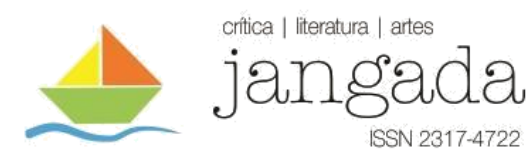

escrita de si de mulheres poetas Mapuche", parte das trajetórias de vida de três escritoras contemporâneas indígenas Mapuche, Maribel Mora Curriao, Graciela Huinao e Rayen Kvyeh, e discute a construção de suas subjetividades no ofício de escrever-se.

Partindo para uma abordagem comparatista, temos os quatro últimos artigos do dossiê. Wanessa Coelho e Juliana Queiroz, com o artigo “A configuração da personagem feminina em A rainha do ignoto, de Emília Freitas, e em El pais de las mujeres, de Gioconda Belli”, realizam um estudo sobre as personagens femininas e discutem como a escritora brasileira Emília Freitas (1855-1908) e a nicaraguense Gioconda Belli subvertem estereótipos femininos em seus romances. Daniel Machado e Angela Guida, em “A condição feminina na poética de Angélica Freitas e Berna Reale", também realizam um trabalho comparativo ao discutir aproximações entre poemas da escritora gaúcha Angélica Freitas e performances da artista visual paraense Berna Reale. Suzane Silveira, com o trabalho "Autoria feminina e parceria textual: o monólogo interior em Marguerite Yourcenar, Lygia Fagundes Telles e Katherine Mansfield", debruça-se sobre contos dessas três escritoras, visando demonstrar aproximações formais e temáticas entre suas narrativas. Karla Santos e Sebastião Lopes, autores do artigo "Mulherio da ousadia: a ressignificação de Capitu a partir das estratégias metaficcionais de Ana Maria Machado em A audácia dessa mulher (2011)", buscam discutir como as estratégias metaficcionais presentes no romance de Ana Maria Machado promovem a ressignificação da personagem Capitu, de Machado de Assis.

A próxima seção é dedicada às contribuições de temática variada, com dois trabalhos sobre a literatura portuguesa. Camila Marchioro, com o artigo “"Agora, que solidão a minha': Camilo Pessanha e o fim de século português", realiza uma revisão crítica do modo como Pessanha teve sua obra vinculada ao Simbolismo. Débora Braga e Allison da Silva, com o artigo "O corpo entre a ausência e o excesso em narrativas decadentistas", analisam representações do corpo em narrativas dos escritores portugueses Mário de Sá Carneiro (1890-1916), Raul Brandão (1867-1930), António Patrício (1878-1930) e Fialho de Almeida (1857-1911).

Chegando do final dessa apresentação, reforçamos que tivemos êxito com o presente dossiê por publicarmos estudos dedicados à análise de trabalhos realizados por mulheres na Literatura, na Música e nas Artes Visuais. Trabalhos de pesquisadoras e pesquisadores que se debruçaram sobre obras de artistas e escritoras estrangeiras consagradas, como Francesca Woodman e Virginia Woolf; da artista brasileira contemporânea, Berna Reale; da escritora que precisa constar na historiografia da literatura brasileira, Emília Freitas; de três escritoras contemporâneas Mapuche, Maribel Mora Curriao, Graciela Huinao e Rayen Kvyeh; de Jangada | nr. 14, jul/dez, 2019 | ISSN 2317-4722 3 | Pág in a 
escritoras brasileiras contemporâneas, como Ana Maria Machado, Angélica Freitas, Conceição Evaristo, Lygia Fagundes Teles etc.

O primeiro artigo do dossiê, de Ângela Froés, analisa o romance Ponciá Vicêncio (2003), da mulher, negra, pesquisadora, escritora, militante, Conceição Evaristo, escolhida como personalidade literária do Prêmio Jabuti de 2019. Na entrevista que publicamos nesse dossiê, Aline Arruda perguntou a Conceição Evaristo sobre o sentido do trabalho com o barro para a personagem Ponciá, ao que ela respondeu: O barro pra Ponciá é a arte. E eu acho que a arte é uma forma de escapatória. Como foi para Bispo do Rosário. A arte te dá a possibilidade de viver no meio de tudo sem enlouquecer de vez. Ela permite suportar o mundo. O ser humano tem essa necessidade.

Boa leitura a todos!

Joelma Santana Siqueira - UFV Natália Fontes de Oliveira - UFV Aline Alves Arruda - IFMG

Editoras deste número 